\title{
The Repercussion of Grief on Childhood in Situations Involving Violent Death
}

\author{
Letticya Fernandes de Oliveira \\ Psychologist, studying specialization in Hospital Psychology \\ Giovanna Lourenço Schreder \\ Psychologist, studying specialization in Hospital Psychology \\ Ellen Fernanda Klinger (Corresponding author) \\ $\mathrm{PhD}$ in Psychology from the Pontifical Catholic University of Goias and professor of the Psychology course at \\ the University of Gurupi \\ E-mail: klingerellen@gmail.com \\ Daniela Ponciano Oliveira (Corresponding author) \\ Master student of the Graduate Program in Psychology, Federal University of Pará and Mental Health specialist \\ E-mail: dponcianooliveira@gmail.com \\ Thamires Reis Amorim
Psychologist, studying specialization in Cognitive Behavior Therapy \\ Aline Ribeiro Dias \\ Psychology Student at the University of Gurupi - UnirG \\ Katylla Amanda Gomes Costa \\ Psychologist, specialist in Mental Health and Legal Psychologyb
}

\begin{abstract}
The death of a loved one can be felt intensely and painfully and, for children, it could generate strong reactions, anguish, and sadness during the grieving process. To analyze the expression of children's loss when facing the violent death of a close people with affective bonds with the child, the research was developed in a School Clinic of Psychology in the Tocantins, having as participants six (6) children with ages between 7 and 10 years old. The information from the interviews with the guardians, through ludic interviews and application of the BDS-IJ test with the children, were interpreted. The results suggest that the children's answers signal the way they have been feeling and where some items indicating areas encompassing mood, thinking, and the social sphere was repeated among the children. We conclude that children have difficulties understanding the period of loss and internalizing feelings related to it. It is important to emphasize that even though the mourning process is difficult, it does matter that the children express their feelings and fantasies, either by playing or through conversation, accompanied by family support to go through this disorganizing period more adequately.
\end{abstract}

Keywords: Violence, Death, Grief, Children, Family.

DOI: $10.7176 /$ RHSS/11-20-02

Publication date:October $31^{\text {st }} 2021$

\section{Introduction}

From the benign to the end of life, human beings face situations of bonds and separations, including the death of some important person in their lives (Bolwby, 2004). It is wondered that how death occurs and its cause should be considered a determinant subject in the elaboration of mourning, possibly becoming one of the most remarkable experiences that one can experience (Kováks, 2007).

The term "death" can be conceptualized in several ways. It is seen by many as the end, and, consequently, a charade that cannot be deciphered. Each perspective, whether philosophical, religious, social, or biological, brings a different perspective and contributes in a particular way to the building of our knowledge about death. Dying has a subjective/personal and cultural meaning. The experience of loss through death is also influenced by the temporal and geographical process, given the ways of dealing with death throughout history (Klinger, 2021).

Also, there is the influence of the way they died, and its types are identified in: expected, as well as in cases of illness; sudden or sudden; by suicide; by violence; and of the son (Soares; Mautoni, 2013). When it occurs unexpectedly, death is remarkable for all family members, as it is a type of death that does not give the loved ones time to prepare (Menezes; Borsa, 2020). It remains empty, with doubts, feelings of abandonment, insecurity, anger, and guilt, as well as the fear of forever losing the object of love (Worden, 2013). 
The occurrence of death by suicide is disconcerting and devastating for those who survive, especially because of the insignificance of unanswered questions as the reason for performing the act; self-blame for not having realized the suicide's intention, in addition to the feeling of shame and the external social stigma (Soares; Mautoni, 2013; Worden, 2013).

Regarding the impact of loss as a result of death by violence, human beings face an enormous challenge and a complex psychological process in the presence of the task of dealing with the experience of trauma and the harsh and violent break of their presumptuous world (Franco; Mazzorra, 2007).

In this way, the mourning process for violent death can be harder to work with, and the consequences for mental health can follow a different trajectory, compared to situations of natural death (Kristensen; Weiseth; Heir, 2012). Unexpected, violent, and premature losses can be considered the most complex to be instituted (Domingos; Maluf, 2003).

According to the World Health Organization (WHO, 2002), the term "violence" is defined as the "intentional use of force or power in a form of threat or effectively, by itself, another person or group or community, which causes or has major contingencies such as injury, death, psychological damage, variations in development or deprivation".

Thus, the real trauma for Winnicott (2000) describes a failure related to dependence, being linked to a stage of the coming of age process. Trauma is like a break in the line of life, in which the idealization of an object is broken by the feeling of anger with the loved one, relative to the object's failure to perform its function.

Azevedo and Pereira (2013) argue that from a historical point of view, grief is a consequence alluding to death, and the elaboration of grief is based on how the individual thinks and behaves in the face of death. In this way, it modifies the subjective aspects of the subject and also the social aspects (Matos; Silva, 2011).

In this plot, rituals are performed in the face of this loss, considering each belief and religion, which is a way of dealing with the loss. Such rites play an important role in the attempt to restore an order that was shaken by death, with its pains, fears, and dangers (Freitas, 2013).

From this perspective, grief is an unavoidable process. Some try to postpone it, but, eventually, it comes. Others, on the other hand, can support it naturally, and some lack the help of professionals to be able to move forward. In case the mourner does not go through the grieving process, it ends up getting stuck at some stage of it, often without noticing it, as the symptoms of an unprepared loss are very similar to other pathologies. The sense of internalized emptiness, perceived in melancholia, is similar to the gap left when something significant is lost. However, the intensity of this emptiness will be equivalent to the way the individual has to deal with fatalities (Peres, 2003).

For Winnicott (2000), mourning is related to the rupture of the affective bond with the lost link. The experience of loss becomes a slow process in the life of a child who notices significant losses since birth. In this way, the child adapts, seeking the process of growth and support in the transitional object, which is used by the child to support the absence of lost love.

As a result, the experience of grief is constantly a challenge for those who experience it. It is considered that mourning for adults stimulates a psychic disorder, however, when it comes to the bereaved child, it can then be more disorganizing, as they are still in a process of psychic and emotional development. Furthermore, children may manifest themselves as depressed, show loss of interest, problems at school, recognition with the deceased, panic, fear, guilt for feeling responsible for what happened, and the manifestation of omnipotent magical thinking (Leandro; Freitas, 2018).

It is noteworthy that the loss of a bond figure is understood by the child as helplessness. Among the most intense and intriguing results bothered by the loss of a loved one are the fear of being abandoned, the longing for the lost figure, and the anger at not being able to find it (BowlbyY, 2004).

Although the child is abundantly young, they already have the emotional capacity to experience and feel the loss, however, their conception of this process will be based on the posture adopted by the family members who should provide the needed attention and care to this child, in such a way that after the period of mourning, the child feels safe and loved by the family members (Rocha; Barretos, 2015). Clarifications need to be given to help them deal with guilt, which can disrupt the grieving process (Lima; Kovács, 2011; Costa et al., 2021).

The child will experience the loss of the one he loves and, for this reason, it must be given an environment so that his pain can exist. The mourning phase ends when the child manages to keep, within itself, the presence of the lost person, even in his absence, and it is this process that involves the establishment of new relationships (Kovács, 2007).

Based on this assumption, the child's understanding of death is in the way the child will deal with this loss and how this mourning will be experienced. The conception of death changes according to the child's age, since the interpretation of certain ideas will be modified at each stage of development, which is linked to the maturity of cognitive processes.

In this context, the research problem intended to answer the following question: What are the manifestations of conflicts and traumas in children who went through a loss involving the violent death of the 
person with whom they had an emotional bond given the events of homicide and suicide? Thus, the purpose of this study is to analyze the expression of child loss in the face of the violent death of close people with emotional bonds with the child, it is expected that this study can contribute to the understanding of child loss due to death due to violence.

\section{Methodology}

It should be noted that this study is included as an addendum to a bigger project, called: "The child and death: the expression of losses, conflicts, and identifications in fairy tales", CAAE ${ }^{\circ}$ 08460919.7.0000.5518, approval opinion under $n^{\circ} 3.970 .957$.

To analyze the expression of childhood lost in the face of violent and traumatic death of close people with affective bonds with the child, this study proposed the realization of a qualitative, transversal, exploratory research, characterized as a multiple case study. Data collection procedures took place between March and September 2019.

The population of this research refers to children from 7 (seven) to 10 (ten) years old, who went through a situation of mourning due to a violent death, whose data come from the major project in which this study is inserted, with a sample of 06 (six) children of both sexes in these conditions. Participants with Intellectual Development Disorder or some intellectual impairment, informed by the person in charge, that makes it difficult to express and understand the statements that make up the Baptist Depression Scale in the Infant-Juvenile version - BDS-IJ test were excluded. (Baptista, 2018).

The institution chosen to carry out the research was the School of Psychology Service (SEPsi) of the University of Gurupi, as it is adequate space for data collection. It is located on Av. Guanabara left. with Rua 09, in the Central Sector of the municipality of Gurupi, Brazil.

Participants experienced situations of loss due to violent death, being subject to the grieving process. Regarding data collection, it was not necessary to conduct interviews with the guardian or the child, using data available from the major project, whose interviews were transcribed and analyzed in full.

For data analysis, continuous readings of the collected material were executed, to identify the resulting content in the interviewees' reports and organize them in a manner congruent with the research objectives.

In addition, the material was analyzed against empirical and theoretical data by the researchers (academics and professor advisor), through the psychoanalytical framework under the Winnicottian perspective as a theory of child emotional development and, for the BDS-IJ test, the manual of correction.

Regarding the BDS-IJ, one of the main differences of the scale is the division of items between positive and negative, which allows the assessment of depressive symptoms also through items with positive responses such as "I have plans for the future and I like myself as I am". The insertion of such elements is aligned with the current point of view that mental health can only be encompassed from the totality of its positive and negative aspects (Machado; Bandeira, 2015).

\section{Results}

From the interview's transcriptions, and also from the BDS-IJ test, the data was analyzed and, lately, an integrated analysis was made, utilizing every material responsible. The Winnicottian Psychoanalytic Theory was the referential used to comprehend the results.

It matters to say that alias names were adopted to the participants, and as well, any information that would not compromise the results were omitted, to protect the identity of children and responsible one.

To elucidate the results, some clinical vignettes of the collected data were selected, with speeches or descriptions of the participants' behavior and actions.

Usually, clinical vignettes are scenes of clinical events that allow us to understand what is going on. The vignette is also defined as: "brief descriptions of events, or situations to which respondents are asked to react. The descriptions are always structured to elicit information about the respondents' perceptions, opinions or knowledge about some studied phenomenon" (Polit; Hungler, 1995).

\subsection{Sample}

Table 1 summarizes the initial data of 06 (six) children bereaved by the violent death of a loved one. Among the participants, two pairs of brothers, João - Pedro and Anastácia-Aurora. From the deaths, during the interviews, it was found that they were of young people, aged between 10 and 38 years, caused by homicide and suicide. Still, in homicides, the triggering factor for the deaths involved conflicts and charged with drug trafficking.

Debating violence becomes a complex context, which is linked to several interconnected aspects. There is an arsenal of conceptions about the violence that, in a way, coincide. It is possible to understand this issue from different angles, such as social issues, others linked to the individual, moral and psychological nature. Such understandings are, therefore, interconnected (Oliveira, 2010). 
Table 1 - Characteristics of children used in the study

\begin{tabular}{|c|c|c|c|c|}
\hline Name & Age of child & Scholarly & Loved one & $\begin{array}{c}\text { Cause of the } \\
\text { death }\end{array}$ \\
\hline Alice & 09 years old & $\begin{array}{l}\text { Registered in the } 5 \text { th year of } \\
\text { Elementary School }\end{array}$ & $\begin{array}{l}\text { Experienced the } \\
\text { mourning of her } \\
\text { father's death }\end{array}$ & $\begin{array}{l}\text { Victim of } \\
\text { homicide }\end{array}$ \\
\hline João & 08 years old & $\begin{array}{l}\text { Registered in the } 3 \text { rd year of } \\
\text { Elementary School }\end{array}$ & $\begin{array}{l}\text { Experienced the } \\
\text { mourning of his } \\
\text { sister's death }\end{array}$ & Victim of suicide \\
\hline $\begin{array}{l}\text { Pedro (João’s } \\
\text { brother) }\end{array}$ & 08 years old & $\begin{array}{c}\text { Registered in the } 3 \text { rd year of } \\
\text { Elementary School }\end{array}$ & $\begin{array}{l}\text { Experienced the } \\
\text { mourning of his } \\
\text { sister's death }\end{array}$ & Victim of suicide \\
\hline Anástácia & 07 years old & $\begin{array}{l}\text { Registered in the First Year } \\
\text { of Elementary School }\end{array}$ & $\begin{array}{l}\text { Experienced the } \\
\text { mourning of her } \\
\text { father's death }\end{array}$ & $\begin{array}{l}\text { Victim of } \\
\text { homicide }\end{array}$ \\
\hline $\begin{array}{c}\text { Aurora } \\
\text { (Anastácia's } \\
\text { sister) }\end{array}$ & 09 years old & $\begin{array}{l}\text { Registered in the } 3 \text { rd year of } \\
\text { Elementary School }\end{array}$ & $\begin{array}{l}\text { Experienced the } \\
\text { mourning of her } \\
\text { father's death }\end{array}$ & $\begin{array}{l}\text { Victim of } \\
\text { homicide }\end{array}$ \\
\hline Lorenzo & 10 years old & $\begin{array}{l}\text { Registered in the } 5 \text { th year of } \\
\text { Elementary School }\end{array}$ & $\begin{array}{l}\text { Experienced the } \\
\text { mourning of a friend's } \\
\text { death }\end{array}$ & $\begin{array}{l}\text { Victim of } \\
\text { homicide }\end{array}$ \\
\hline
\end{tabular}

\subsection{Initial Interviews}

Notably, the following information is data available from the major project. Thus, the initial interviews occurred with the guardians, in which the anamnesis was used, being one of the essential elements for the understanding of important aspects of the child's life (Cunha, 2003, p. 50). The children were attended individually, with the application of the BDS-IJ, showing the following results:

3.2.1 Alice

Interview (Anamnesis) with the person responsible for Alice: Realized with the paternal grandmother, whom the child considers as a mother and raised her since she was 08 (eight) months old. Alice has almost no contact with her biological mother, who lives in another city. Upon receiving the news, communicated by another person, in the presence of the grandmother, who was also known of the fact at that time, the child remained paralyzed, without reaction. She cried all night, and according to the grandmother, the child was crying desperately. After her father's death, Alice doesn't like to talk about it, tries to change the subject when they start a conversation, not being able to establish a dialogue to explain the loss of the child.

Grandmother: I was at work when the woman who lived with him called, saying what had happened, who had killed him, then it happens that I arrived home desperate from work, then I arrived at the door gate almost fainting, right, then I already I said: "they killed your father, baby"; then she panicked, totally paralyzed, then I got sick and went to the UPA (Public Health Unit). They took me to the UPA, then my baby arrived there and they took me there, then that's where she found out, right. [...] Yes, she was desperate, then there was no way.

Researcher: Did you guys (grandmother and Alice) talk about it later?

Grandmother: No, but, even so, we talk a lot. Even when (Alice) talks about him, it seems like she feels in some way like is something she doesn't like to hear, then she leaves or changes the subject.

Researcher: So, what difficulties did you have in talking to Alice? The moment you reported was that moment that arose, how was she at that time?

Grandmother: At the moment she was like that, it seems she did not react. Then, during the day, everything was fine, then during the night, she started crying, crying in despair.

According to the guardian's report, Alice was a more energetic and happy child, and that her behavior change is related to an increase in sadness. The grandmother also reports that her granddaughter even fainted and complained of great sadness, but refused to talk about her father's death.

Playful interview with Alice: It was observed, in the initial interview, that Alice is a child with good communication, smartness, and sharp-minded. She didn't talk about her father. When she answered, it was in a very low tone and always monosyllabic in the answers (yes, no, I don't know). Curious about being in the office, active, inquisitive. Physical appearance: good looking, wealthy with neat clothes. Confident posture. 


\subsubsection{João and Pedro}

Interview (Anamnesis) with the person responsible for João and Pedro: Conducted with the mother. The news of her sister's death was offered by her mother in simple language and without further details. The children were apprehensive after their sister's death, asking questions about the reason for the event. However, currently, they no longer ask. As for the expectations with the children, the mother reported that they grow up psychologically and spiritually healthy and with a balance of feelings.

Researcher: After the sister's death, did you notice any change in their behavior?

Mother: There were changes, right, they were very apprehensive about the event, the concern to know why it happened, where she was and stuff, why that happened, it happened because she was with bad people, so we always heard very isolated questions from them.

Researcher: And now, they keep asking?

Mother: No, they don't ask anymore.

Researcher: But they used to speak right?

Mother: They did.

Researcher: And who used to answer these questions?

Mother: We always used to say, the sister is now living with The Lord in heaven, now she is in another life, she is there, a little star in the sky, she is there. Why did she die? Because she was with bad people; they said, right. Mom, why our sister. died?

Playful interview with João: In João's initial interview, the child was slightly withdrawn and a little bit shy, facing some difficulty in elaborating the answers during the talk with the researcher. Physical appearance: good looking, wealthy with neat clothes. Slightly stooped posture.

Playful interview with Pedro: It was observed from that initial interview that Pedro is a child with good communication, reading, and interpretation. During the interview, he talked about his sister. Curious, active, and interested in being in the office. Physical appearance: good looking, well taken care of with lined clothes. Confident posture.

\subsubsection{Anastácia and Aurora}

Interview (Anamnesis) with the person responsible for Anastácia: According to information from the mother, Anastácia, the youngest daughter, unplanned pregnancy, born by cesarean section with strabismus, breastfed until 9 months. She has no problem with language. Currently, she has difficulty sleeping and wakes up wanting to cry. Sleeps with the mother. The child is not eating well, as she used to eat from the same dish as the father. At school, due to the father's death, the child cries all the time, is silent, and does not usually get attached to friendships.

Researcher: How did the children find out about their father's death?

Mother: It was that panic, right? Right in time, my girl arrived terrified saying it, right? Then she got into despair.

Researcher: Did she find out from whom?

Mother: No, it was desperation, right? [Another person] came saying that they shot him, that they killed him. Then they listened, they started to cry, scream. (Aurora did saw where her father was dead, near her house)

Researcher: And did you hear from them?

Mother: No, it was close to my house, like, on the corner. Then at the funeral, she (Anastácia) suffered a lot, you know, she cried, she screamed, she was desperate.

Researcher: She participated in the ritual, right, at the funeral?

Mother: Hmm, she got all burned like that, she's white, right, she turned red, so she burned everything, like that.

Researcher: From crying so much?

Mother: Hmm, and whoever arrived at the funeral suffered for her, right, the way she was.

The child had a referral from the school, for crying, sadness, learning difficulties, and refusal to participate in activities.

Playful interview with Anastácia: Anastácia was withdrawn, which is not uncommon due to the moment in her life, and that being the first contact with the researcher. Demonstrated experiencing anguish, caused by her father's death. During the interaction, she made eye contact and reported on the object of attachment she has from her father. When she answered the BDS-IJ, it was in very low tones. There was certainly a need for support for her emotional development. Physical appearance: good looking, wealthy, with neat clothes. Slightly stooped posture.

Interview (Anamnesis) with the person responsible for Aurora: She has had difficulty sleeping since she 
was little, she sometimes wakes up agitated, as if she were afraid of something. After her father's death, Aurora wakes up startled, saying that her father was in bed lying down. Sleeps with the mother. Likes to go to school, has no difficulty studying.

During the interview, aspects relevant to the understanding of the case were observed, such as the fact that the mother did not know important information about the daughters (Anastácia and Aurora), such as the name of the teacher, which children liked to read and their favorite stories, confusion when saying the number of children "I can't even count" (sic).

The mother, who has difficulty with the death of her father is Anastasia because she talks about missing her, cries, complains, has complaints coming from the school. Aurora, on the other hand, is quieter, has good academic performance, and has not complained, which can refer to the perception that she does not understand or was not so affected by the loss. However, relevant data is that Aurora witnessed the situation of the finding of the dead father's body near his house.

Playful interview with Aurora: Aurora was withdrawn, with little verbal and visual contact. When he answered, it was in a very low tone. Visibly restless. It presents a need for support and security. Physical Appearance: Good looking, well taken care of with lined clothes. Bent posture.

3.2.4 Lorenzo

Interview (Anamnesis) with the person responsible for Lorenzo: Realized with the mother. According to the information presented by the mother, the child was born through normal birth, breastfed for up to 1 year and 6 months. He does not present or has presented any language, writing, and speech problems. He sleeps in the same room as his parents. He's been a quiet child since he was a baby. When he gets nervous, he feels like throwing up. It has already been to a specialist doctor, in which he was diagnosed with gastritis. The mother reports that Lorenzo was a normal child who liked to talk and who currently prefers to be alone.

Regarding the friend's death, the mother reports that on the day of the occurrence, Lorenzo's father picked him up earlier at school. Through the news on tv, the child learned that his friend had been shot, was hospitalized, but unfortunately, he did not resist. Lorenzo's mother, upon hearing the news once more on the tv, decided to tell her son directly, Lorenzo cried. After his friend's death, Lorenzo presents somatization, crying, and sadness.

Researcher: It was you who spoke. You find out through...?

Mother: From the news on tv.

Researcher: And what came into your mind at the time it was reported, what did you think?

Mother: I didn't know it would be such a shock, but since everyone was aware, I preferred him to know by me and not at school, so it was like that.

Researcher: And how did you tell? How was it?

Mother: I arrived and said: Lorenzo, your little friend did not resist and he died; he started to cry, he said he was afraid of going to school, being hit by misguided bullets, he said he was afraid of the same thing happening to him too, then we even spent some time, because he used to go alone to school, right? Alone on a bicycle, then I spent some time escorting him due to fear. I followed him to school, but the F5 was a lot, so we noticed that he was shocked, a lot, right? And, to make matters worse there was this thing about his father with the Grandma right, then with F5, I think I was trying to solve these problems, I don't know, I think it triggered this.

Playful interview with Lorenzo: It was observed, in the initial interview, that Lorenzo was apprehensive about the contact, showed some discomfort and anxiety, which we sought to reduce with the establishment of rapport. He answered the test questions in a very low tone and was always monosyllabic in the answers (yes, no, I don't know). Reluctant to be in the office, although he doesn't verbalize it. Physical appearance: good looking, wealthy, with lined clothes. Slightly stooped posture.

\subsection{BDS-IJ}

About the result of BDS-IJ, Table 2 presents scores and results obtained. 
Table 2 - Result BDS-IJ (scored items)

\begin{tabular}{|c|c|c|c|c|c|}
\hline Nome & Age & Score & $\begin{array}{l}\text { Most pointed } \\
\text { descriptors }\end{array}$ & Specifications & Answers \\
\hline Alice & 09 years & 1 & Humor symptom & $\begin{array}{l}\text { Article } 9 \text { "I want to do the } \\
\text { things I like" }\end{array}$ & Sometimes \\
\hline João & 08 years & 7 & $\begin{array}{l}\text { Social symptom } \\
\text { Cognitive } \\
\text { symptom } \\
\text { Humor symptoms }\end{array}$ & $\begin{array}{c}\text { Article } 2 \text { "I feel like being } \\
\text { away from my family" } \\
\text { Article } 5 \text { "I feel guilty" } \\
\text { Article } 8 \text { "I feel sad" } \\
\text { Article } 13 \text { "I have some } \\
\text { good days" } \\
\text { Article } 17 \text { "I'm happy with } \\
\text { my life" }\end{array}$ & Sometimes \\
\hline Pedro & 08 years & 14 & $\begin{array}{c}\text { Cognitive } \\
\text { symptoms } \\
\text { Social symptom } \\
\text { Humor symptoms }\end{array}$ & $\begin{array}{l}\text { Article } 12 \text { "I believe in a } \\
\text { brighter future" } \\
\text { Article } 14 \text { "I have plans for } \\
\text { the future" }\end{array}$ & Sometimes \\
\hline Anastácia & 07 years & 13 & $\begin{array}{l}\text { Humor symptoms } \\
\text { Cognitive } \\
\text { symptoms }\end{array}$ & $\begin{array}{l}\text { Article } 13 \text { "I have some } \\
\text { good days" } \\
\text { Article } 14 \text { "I have plans for } \\
\text { the future" } \\
\text { Article } 16 \text { "I believe in my } \\
\text { abilities" } \\
\text { Article } 18 \text { "I can focus on } \\
\text { my tasks" }\end{array}$ & $\begin{array}{l}\text { To articles } 13,16 \text {, and } \\
\text { 18, answered: "Never/ } \\
\text { few times". In article } 14 \text {, } \\
\text { she answered } \\
\text { "Sometimes" }\end{array}$ \\
\hline Aurora & 09 years & 3 & Humor symptoms & $\begin{array}{c}\text { Article } 7 \text { "I cry" } \\
\text { Article } 8 \text { "I feel sad" } \\
\text { Article } 9 \text { "I want to do the } \\
\text { things I like" } \\
\text { Article } 15 \text { "I have slept } \\
\text { well" }\end{array}$ & Sometimes \\
\hline Lorenzo & 10 years & 4 & $\begin{array}{l}\text { Humor symptoms } \\
\text { Cognitive } \\
\text { symptoms }\end{array}$ & $\begin{array}{l}\text { Article } 1 \text { "I feel weird and } \\
\text { I don't know why" }\end{array}$ & Sometimes \\
\hline
\end{tabular}

As can be seen in Table 2, the percentage of participants ended up being classified in the category with no indication of depressive symptoms, presenting a normative of "Positive behavior". However, although no score is not indicative of depressive symptoms, in general, the child's responses indicate the way they have been feeling and where some indicative of areas including mood, thinking and the social sphere were repeated among the children.

The mood and cognitive spheres were the ones that had the most items marked, with 16 and 10 items respectively. Mood includes sadness, loss of interest and/or pleasure, crying spells, diurnal mood shifts. To cognition, it includes hopelessness, helplessness, ideas of guilt (which can reach delusions of guilt in a psychotic depression) and suicide, indecision.

\section{Discussion}

In the analysis of the results collected from the interviews and tests, three thematic branches stood out, involving: feelings in the face of losses due to death; secondary or death losses, and fear of death or of losing another family member. It should be noted that, even though the topics appear separate in this study, they (topics or thematic branch) meet, intertwine.

\subsection{Feelings about loss}

Losses due to homicide, including drug use and suicide, represent a greater difficulty to be shared since in addition to being constantly surrounded by unknown information, they raise doubts about the moral integrity of the victims themselves and even of the survivors, which end up being the target of prejudiced and moralistic attitudes.

In this way, how to describe mourning, as this is an undeniably grieving process accompanied by such a unique and immeasurable feeling? The participants of this study demonstrated that when facing the loss of a loved one, they face the pain and helplessness of those who will not return. Each of the children experienced and still experiences grief individually, and may express similar feelings, but somehow there is no way of 
comparison, as the loss, as well as any other type of feeling, is not measured or similar, at all.

In this sense, Silva and Ferreira-Alves (2012) argue that mourning is a complex event, whose process and consequences are influenced by the interaction of a series of singularities, specifically: coming of age, personality, cognitive development, social development, and the environment in which they live. Corroborating, Paiva (2011) elucidates that, with the passing of chronological age and cognitive maturation, the child starts its progressive understanding of finite concepts, until reaching puberty, which is the end of the cycle of total knowledge about the subject. In this way, each child will confront, in their way, the reality of the loss of the beloved object (Kovács, 2003).

It should be noted that, for this research, the issues related to age and grief refer to cognitive understanding, to the conformity in which the child develops; however, without affirming or defending that there is specific mourning in childhood or that the child does not perceive death, or even that they have different feelings when devastated by the loss due to death.

Therefore, it is undeniable that the same dimension cannot be attributed in terms of understanding death, in terms of concepts and cognitive acquisitions, between a child and an adult or between a 3-year-old and a 10year-old child; but it is necessary to emphasize that the position defended considers the differences as arising from aspects of cognitive development and modes of communication. There is no grief that is specific to childhood.

Still, there are issues and characteristics of growing up that can interfere with the child's emotional development, which is not oblivious to death and is not necessarily more or less sensitive than an adult with the loss of a loved one, as illustrated in the following showcase.

In a certain moment of the playful interview with Anastácia, she brings content from her phantasmatic world (fantasies).

Researcher: [I know] that something very sad happened to you, to you and your family, which was your Dad [death], right? That Dad is no longer here, he died, right? And you were very sad, that you don't want to go to school anymore, that you've been crying, can you tell if that's it? What happened to you? (explanation of the reason for seeking care for the child)

Anastasia: (Slight smile). Nothing.

Researcher: Nothing happened. And Dad?

Anastasia: Also nothing.

Researcher: You miss him right and sometimes you feel sad.

Anastasia: (Nods head in confirmation). My mom and I sleep in his shirt.

Researcher: Do you sleep in his shirt?

Anastasia: His clothes.

Researcher: Do you sleep in his clothes to smell them?

Anastasia: (Nods head in confirmation).

From this excerpt, it is possible to see that Anastácia brings the symbolism of the object of attachment; transitional, reflecting her feeling of abandonment and loneliness. According to the Winnicottian theory, a transitional object is the object of the external environment that it exchanges, and on which the child depends to guarantee its existence. Fantasies appear as a way of dealing with an undesirable internal reality, as a defensive process, in the search for being able to deal with the internal reality, through the use of an omnipotent control of external reality (Winnicott, 1975).

Regarding the ability to fantasize, Winnicott (2000) turns to the subject's primitive emotional development, understanding that fantasies come early and refer to the primitive experiences of each subject, in terms of satisfaction, frustrations, pleasurable and painful sensations of childhood. The appearance of fantasies is a psychic process that allows the adjection between internal and external realities, as it intertwines contents, objects, and desires.

This same ability to fantasize, which can be a link to the passage and interconnection between internal and external realities, can also present moments of interruption of this connection (WINNICOTT, 1975). Therefore, such ability can be understood as a healthy aspect of the individual to deal with the loss, as long as the fantasy is not greater and prevents the perception of reality, being only part of the capacity to transition necessary to repair what was lost (Barone, 2004).

This research understands fantasy as a creative and restorative capacity that will culminate in the child's acceptance of death, in which the concrete experience of death is related to the child's constitution of fantasies. However, support is needed for the bereaved child to go through the grieving process without other developmental complications, where trauma has greater proportions.

It was observed that children bereaved by unexpected deaths showed characteristics of separation anxiety related to the loved one. From this perspective, the loss of the object of love for the children under study refers to a unique experience and implies particular mourning, since the adaptations that the bereaved need to face both at 
an individual and social level are immeasurable.

\subsection{Losses secondary to death}

The children in the study demonstrate that, even though they are unable to express themselves through speech, due to their level of cognitive development, they already can perceive what happens around them, including death (Aberatury, 1984).

Some authors consider that the type of death can cause a gap in the human being's life about the lost figure, causing a psychic and emotional rupture in the life of those who go through this type of traumatic circumstance. The main characteristics of trauma are related to intrusive images, with the person reliving the situation that traumatizes them (Franco; Mazorra, 2007; Soares; Mautoni, 2013; Worden, 2013).

According to what was analyzed, it is noted that children have secondary losses, where mourning is represented in different ways due to the link established with the lost figure. In the face of the mourning process, it is necessary to understand the link established between them, that is, child and loved one; to consolidate the emotional and psychological development of that child. Thus, the loss of a loved one is already a long and laborious process, the existence of secondary loss during the occurrence of a bereavement that has not yet been finalized alters child development, in which it has the potential to bring with it issues of previous grief, that is, the feelings they feel after terminating with a significant affective bond encompass negative experiences that can bring serious consequences.

It is important to address the issue of understanding the lack, deprivation, or deprivation in the Winnicottian perspective, of gratifications provided in the past by the deceased one, associated with sadness, crying and anger, which is reactions to secondary losses, this being a concern expected by children (Winnicott, 2000).

Anastácia: My grandfather died too.

Researcher: Your grandfather died too. Are you sad about it?

Anastácia: (Nods head in confirmation).

Researcher: Yeah. And did you know him?

Anastácia: (Nods head in confirmation).

Anastacia's case reveals an expression of hope for the search for lost care. The child went through the deprivation process because, in addition to the paternal loss, this child had another significant affectionate loss, her grandfather's, which was an important phase for her emotional development process. Here, situations such as deprivation are understood, which may be related to a failure in the environment during the stage of relative dependence, after reaching individual identity, that is, the child had a good start, had already sufficiently established maturity to have the perception that the loss was caused by the environment, but as a result of the experience of a new loss, one perceives the flaws in the environment and reappears the feeling of distress considered by the child as intolerable in face of the loss (Winnicott, 2000).

\subsection{Fear of death and lose another family member}

The anxiety and fear of death and the loss of another family member manifested in the children's fantasies, presenting an unreal understanding of death. The way the children received the news of the death of a loved one demonstrates a gap, that is, the search for answers becomes constant, related to the feeling of the anguish of not having an understanding of the cause of death. Thus, the understanding of death and the feelings coming from the loss is affected when adults omit it (Winnicott, 2012).

Pedro and João did not get clear explanations about how their sister's death happened, for some time they carried out inquiries to try to understand what had happened. However, those responsible sought ways to remain silent about the truth, creating an information gap, which consequently harms children in their construction of meanings.

Aberastury (1982) assures that when an adult refuses to verbally clarify the death, it disturbs the initial moment of elaboration of the child's grief, which is the acceptance that someone has disappeared forever. Explanations such as "went to heaven", "went away for a trip", "is sick", or "they will soon return", generate confusion and pain, as well as permanent frustration for the child, blocking the entire process of knowledge. "The absence becomes more painful and conflicting. A conviction of what happened that is perceived by the child and what the adult reports to them enter into battle" (p.132).

Through Lorenzo's symbolic manifestations and his anxious, introverted, and suspicious behavior, one can see the impact and consequences of the loss of his friend. As Klein (1996) states, through a representation, the child expresses their fantasies, anxieties, and in this way, they manage to alleviate this situation, making the ability to play effectively for their development. Children can share information in the same way through their body expression: due to difficulties in knowing how to express themselves, they demonstrate pain through aggressive behavior and irritability.

Researcher: The reason you're here is that something happened to you last year. Not exactly with you, but with you in your school, didn't it? How did it affect you? 


\author{
Lorenzo: Hmmm. \\ Researcher: Made you a little bit sad? \\ Lorenzo: Yeah. \\ Researcher: And this year did you remember that? \\ Lorenzo: I did.
}

In this excerpt, it is evident that Lorenzo is unable to express himself about his friend's death, even though he has memories, he has difficulties in externalizing his feelings. The silence of the child who does not oppose the circumstance experienced implies the need for the words of another to help them understand the experience.

We noticed that the feeling of guilt for the loss prevails among children. Through this conception, the somatization of death symbolizes a defense mechanism against the absence of the loved one, because for an unconscious individual to exist, there must be a separation from the first signifier. Thus, in the process of separation from the love object, children repress experiences of satisfaction that are brought about through somatic symptoms. For Silva (2018, n.p), "it is from the other that the subject is constituted, therefore it is an essential task in the constitution, leaving the place of the other's object and reaching oneself as the desired object".

Winnicott (1983, p. 60) assures that 'the skin becomes the limit of the 'Me' and the 'Not Me', in other words, the psyche starts to live in the soma and a psychosomatic life begins". Thus, it is noticeable that are manifestations of suffering in children, the emergence of symptoms, and behavioral difficulties, which are often not understood by parents as reflections of the loss.

Part of Pedro's interview follows, in which he expresses through drawing the identification of the environment with his sister's death. Furthermore, the child shows memories of the absence of his sister, the feeling of missing someone.

Researcher: Takes a paper sheet and asks P to draw a house.

Peter: A house?

Researcher: Yes

Peter: Anyway?

Researcher: Any way you want.

$P$ starts to draw, after a few minutes he tells the Researcher that he is finished.

The researcher then asks:

Researcher: How many floors are this house?

Pedro: Just one.

Researcher: Is it your own house?

Pedro: No.

Researcher: Whose is it?

Pedro: Nobody.

Researcher: Nobody?

Pedro: I just remembered beautiful houses

Researcher: Ahh! He remembered beautiful houses. What is this house made of?

Pedro: Wood and stone.

Researcher: What house were you thinking of?

Pedro: In a building, where my home was.

Researcher: Would you like this house to be yours?

Pedro: No.

At another moment, the researcher asks Pedro to draw a person, who asks the following questions:

Researcher: Draw a person now.

Pedro: Could it be my sister, or something normal?

Researcher: Draw whoever you want.

After some time, Pedro tells the Researcher that he has finished the drawing.

Researcher: Is this person a boy or a girl?

Pedro: It's a girl.

According to Winnicott (2000), the use of creativity is the foundation of well-being. In this way, through drawing, it became possible to express the manifestation of Pedro's fantasies, which is an essential event for the projection of his conflicts, in addition to showing his relationships in the here and now.

Given the points presented, right after the loss, the mourning process begins, in which the child gradually recovers until reaching a state in which they consider themselves neutral. During the grieving process, children experienced and still experience traumas and conflicts coming from grief in childhood and losses in situations involving death, and during childhood, it is more difficult for children to understand the meaning of death. The suffering lasts until the hope of restoring the good environment that he had comes back, and it is in this moment of hope that the child starts to commit antisocial acts. 
It is perceived that approaching and working with the theme of death is a delicate task, surrounded by pain, fears, and taboos, which, together with the theme of childhood and mourning, denotes greater proportions and complexity, as the child is still attributed to lack of knowledge about death. Furthermore, the study reflects the experiences expressed by these children and the vulnerability of the bereaved with the loss of loved ones.

\section{Conclusion}

This study achieved the proposed objective of analyzing the expression of child loss in the face of violent and traumatic death, presenting the correlations to the child's expression and its grieving process. It was noticeable that the reaction to the loss of someone significant depends considerably on how the death will occur, the degree of bond established with the loved one, and how the child will receive the news of the loss.

From this perspective, it is clear that the children presented in the study have difficulties in understanding the period of loss and internalize feelings related to it. As a result, the study confirmed that children in the process of mourning have feelings of helplessness and sadness, changes in behavior; such as regression in their cognitive, emotional, and social intelligence, insecurity and guilt; and difficulties in expressing pain.

It is noteworthy that as difficult as the grieving process is, the child needs to express their feelings and fantasies, either through play or dialogue, accompanied by family support to go through this disorganizing period, in a way more suitable. Communication about the loss of the significant person should be clear, using language appropriate to their age and cognitive and emotional maturity. In this way, the child gets the clarification of doubt, their grief process begins to be elaborated.

It is understood that the researched topic is of great value and should be further discussed, as there are not many studies talking about violent death and children, and this study can help them to understand what they experience, thus contributing to their process of elaboration of the loss. Thus, the relevance of the research is given by obtaining the updated study that will contribute to the performance of professionals in the care of bereaved children, involving the search for knowledge about psychological practices and intrapsychic mechanisms involved in the elaboration of the child's grief.

In the current context, of deaths involving the pandemic scenario, children notice the feeling of apprehension of their families in the environment in which they live. Thus, these children have the potential to manifest feelings confederated with secondary losses, developed due to the loss of a loved one. Therefore, it is clear that at any age, tragic events can trigger ancestral mourning, recalling old and current feelings with their psychic consequences.

\section{References}

Aberastury, A. (1982). Conflicts in the elaboration of mourning. Psychoanalysis of Child-Theory and Technique. Azevedo, A. K. S., Pereira, M. A. (2013). Grief in the psychological clinic: a phenomenological look. Natal, Brasil. Revista Clínica \& Cultura, 2 (2), (pp. 54-67).

Baptista, M. N. (2018) Baptist Depression Scale-Infant-Juvenile Version (BDS-IJ). Itatiba, SP: University San Francisco University San Francisco.

Barone, K. C. (2004). Reality and mourning: a study of transitionality. São Paulo: Casa do Psicólogo.

Bowlby, J. (2004). Formation and disruption of affective bonds. São Paulo: Martins Fontes.

Costa, K. A. G. et al. (2021). The perceptions and difficulties of the adult in the communication of death to the child. International Journal of Development Research, v. 11, 2021. Available at: https://doi.org/10.37118/ijdr.21612.04.

Cunha, J. A. (2003). Psychodiagnosis - V. 5 ed. Porto Alegre: Artmed.

Domingos, B., Maluf, M. R. (2003) Experience of loss and mourning in schoolchildren aged 13 to 18 years. Psicologia: Reflexão e Crítica, 16, 577-589.

Franco, M.H.P E Mazorra, L. (2007). Child and mourning: fantasist experiences in the face of the death of the father. Estudos de psicologia. (Campinas) [online], vol. 24, n. 4, pp. 503-511.

Freitas, J. de L. (2013). Grief and phenomenology: a comprehensive proposal. Revista da Abordagem Gestáltica, 19(1): 97-105, 2013. Available at: $<$ http://pepsic.bvsalud.org/scielo.php?script=sci_arttext\&pid=S1809$68672013000100013>$.

Klein, M. (1996). Grief and its relations with manic-depressive states (1940). In: Klein, M. Love, guilt and repair and other work (1921-1945). Complete Works of Melanie Klein. Vol. I, Rio de Janeiro: Imago, 1996.

Klinger, E.F. (2021) A Criança e a Morte: a expressão das perdas e conflitos por meio dos contos de fadas. $212 \mathrm{f}$. Thesis (PhD in Psychology). Pontifica University Catholic of Goiás - PUC, Goiânia.

Kovács, M. J. (2007) Morte e desenvolvimento humano. São Paulo: Casa do Psicólogo, 2007.

Kristensen, P., Weiseth, L., Heir, T. Luto Parental Em Situações De Morte Inesperada: Reações À Perda, Estratégias De Coping E Perceção De Qualidade De Vida. Thesis dissertation, University Of Lisbon Faculty of Psychology.

Leandro, J. C. Freitas, P. M. L. (2018). Luto Infantil: A Vivência Diante Da Perda De Um Dos Pais. Revista 
Uningá, [S.1.], v. 46, n. 1, jan. 2018. ISSN 2318-0579. Available at:< http://revista.uninga.br/index.php/uninga/article/view/1228>.

Machado, W.L \& Bandeira, D.R. (2015). Tri-analysis of the Baptist Depression Scale of Child and Juvenile and the Children's Depression Inventory. Porto Alegre; 49(4), 339-347, SSN 1980-8623. Available at: $<$ https://revistaseletronicas.pucrs.br/ojs/index.php/revistapsico/article/view/26866>.

Matos-Silva, M. S. (2011). Teclando com os mortos: um estudo sobre o uso do Orkut por pessoas em luto. Thesis (Doctorate in Clinical Psychology) - Pontifical Catholic University of Rio de Janeiro, Rio de Janeiro. p. $51-71$

Menezes, K. J. S., Borsa, J. C. (2020). The death of parents by homicide and child grief: systematic review. Psicologia: teoria e prática, 22 (2), 406-428. Available at: <https://dx.doi.org/10.5935/19806906/psicologia.v22n2p406-428>

Paiva, L. E. (2011). A arte de falar da morte para crianças: a literatura infantil como recurso para abordar a morte com crianças e educadores. Aparecida, SP: Ideia \& Letras.

Peres, U. T. (2003). Luto: colaboração da psicanálise na elaboração da perda. Rev. Psicol. Saúde e Debate. Dez. 2003 Available at:< http://psicodebate.dpgpsifpm.com.br/index.php/periodico/article/view/167>.

Polit, D., Hungler, B. (1995). Fundamentos de Pesquisa em Enfermagem. Porto Alegre, Artes Médicas.

Rocha, M. V. Barreto, J. B. M. (2015). A Ludoterapia No Processo Do Luto Infantil: Um Estudo De Caso. Research in Psychology/Electronic Activities. University of the West of Santa Catarina. Available at: $<$ https://portalperiodicos.unoesc.edu.br/pp_ae/article/view/8555>.

Silva, Fabiana Álvores de Abreu (2018). A dor e a delícia de tornar-se adulto: o processo de alienação e separação na constituição do sujeito. APPOA.

Soares, E. G. B.; Mautoni, M. A. de A. G. (2013). Conversando sobre o luto. São Paulo: Ágora, 2013.

Winnicott, D. W. (1983).The environment and maturation processes - Studies on the theory of emotional development. Porto Alegre: Artmed.

Winnicott, D. W. (2000). From Pediatrics to Psychoanalysis (D. Bogolometz, trad.) Rio de Janeiro: Imago, (Original work published in 1958).

Winnicott, D. W. (2012). From Pediatrics to Psychoanalysis. Rio de Janeiro. Imago.

Winnicott, D. W. (1975) Play and reality (J. O. A. Abreu \& V. Nobre, trades.). Rio de Janeiro: Imago, (Original work published in 1971).

WHO. World Health Organization. (2002). World Report on Violence. Genebra.

Worden, J. W. (2013). Grief and loss therapy: a manual for mental health professionals. São Paulo: Roca, 2013. 